\title{
The Effect of Salinity Stress on Seed Germination of Red Clover (Trifolium pratense L.) and Alfalfa (Medicago sativa L.) Varieties
}

\author{
Monica NISTE, Roxana VIDICAN*, Vlad STOIAN, Ioana BERINDEAN, Adriana CRISTE, Raluca MICLEA, \\ Rodica POP \\ ${ }^{1}$ University of Agricultural Sciences and Veterinary Medicine, ClujNapoca, Faculty of Agriculture, \\ Manastur Street, No. 3-5, 400372, Cluj-Napoca, Romania, \\ ${ }^{2}$ University of Agricultural Sciences and Veterinary Medicine, ClujNapoca, Faculty of Horticulture, \\ Manastur Street, No. 3-5, 400372, Cluj-Napoca, Romania, \\ ${ }^{3}$ University of Agricultural Sciences and Veterinary Medicine, ClujNapoca, Faculty of Animal Science \\ and Biotechnologies, Manastur Street, No. 3-5, 400372, Cluj-Napoca, Romania \\ *Corresponding author: roxana.vidican@usamvcluj.ro
}

Bulletin USAMV series Agriculture 72(2)/2015

Print ISSN 1843-5246; Electronic ISSN 1843-5386

DOI 10.15835/buasvmcn-agr: 11706

\begin{abstract}
Salinity is one of the environmental factors that has a critical influence on the germination of seeds and plant establishment. Salinity affects imbibition, germination and root elongation. However, the way in which $\mathrm{NaCl}$ exerts its influence on these vital processes, whether it is through an osmotic effect or a specific ion toxicity, is still not resolved. The objective of this study was to compare the salinity tolerance of two varieties of red clover (Select 2 and Rotrif) and two varietis of alfalfa (Mihaela and Mădălina). In our study we used five salinity treatments 0 (control) (C1), 50 (C1), 100 (C2), 150 (C3) and 300mM NaCl (C4) on normal seeds and seeds inoculated with rhizobia. 100 seeds of each variety used in the study were grown in germinating dishes on filter papers with four replications. The results showed that by increasing of the salinity level, germinated seeds number, root, shoot and seedling length, mean daily germination (MDG) and seedling length vigor index (SLVI) decreased, while daily germination speed (DGS) increased in all studied varieties. Mean germination time increased with increasing $\mathrm{NaCl}$ level. As the salt concentration increased, germination percentage decreased in all varieties, moreover, seeds could not germinate in $300 \mathrm{mM} \mathrm{NaCl}$, but the seeds who were bacterized germinated in a very small percentage, and the germs were abnormal.
\end{abstract}

Keywords: germination, salt stress, tolerance, vigor.

\section{INTRODUCTION}

Soil salinity is an issue that affects an estimated $6 \%$ of the world's land surface area or 12.780 million hectares (Mha) and secondary salinization from irrigation impacts an estimated $20 \%$ of irrigated land or 1474 Mha. Salinity is a complex issue to characterize due to the many factors that influence a plant's response to salinity, including: plant, soil, water, environmental and cultural factors (Scasta et al., 2012). A decrease in plant growth in salinity soils is caused by the osmotic and water potential of soil, specific toxicity, and nutritional deficit. After these primaries effects, secondary stresses happen as the oxidative damage, some physiological symptoms associated with the toxicity of the ions are: membrane perturbations and damage in organelles; decrease or inhibition of the enzymatic activity, inhibition of the photosynthesis, change in stress hormone (Castroluna et al., 2014), phytotoxicity of ions such as $\mathrm{Na}^{+}$and $\mathrm{Cl}^{-}$and nutrient imbalance depressing uptake and transport of nutrients (Hasanuzzaman 
et al., 2013) .These metabolic changes determine a decrease in plant growth; and consequently, the plant dies (Castroluna et al., 2014).

Plants differ in their tolerance to salt. Alfalfa (Medicago sativa L.) is one of the most important forage crops and has high protein and highly digestible fiber contents. It can be cultivated in moderate salt-alkaline soils and has been widely cultivated as an economic crop worldwide (Ruili Li et al., 2010). Salinity reduced water potentials in the leaves of clovers (Trifolium sp.), reduced length and dry mass of the stem and affects the length and conductivity of the root (Orak and Ateş, 2005).

Salinity is a major environmental stress factor that affects seed germination. Salinity resistance of germination seeds of forage rape, berseem clover, alfalfa, and red clover has been shown to be a heritable trait which could be used as an efficient criterion for the selection of salt-resistant populations (Mandić et al., 2014). Salinity constraint affects seed germination either through osmotic effects, by preventing or delaying germination. This abiotic factor can reduce germination through ion toxicity, which can render the seeds unviable. Although high salinity may inhibit germination, this effect may itself depend upon the prevailing temperature at the germination stage (Benabderrahim et al., 2011).

Germination and seedling characteristics are the most viable criteria used for selecting salt tolerance in plants. Germination percentage, germination speed and seedling growth are the most useable criteria for cultivar selection (Ozlem Onal Asci, 2011).

Root hair formation is also reduced by increased solute concentration in the germinating environment. Root hairs are critical in nutrient extraction from the rhizosphere, and reduction in roothair formation inhibits seedling establishment. Screening for seeds with a greater tolerance to salt stress aids in the development of salt tolerant cultivars. Screening for seeds with a greater tolerance to salt stress aids in the development of salt tolerant cultivars. Seed germination is a critical point in seedling establishment and subsequent plant health and vigor (Ashkan and Jalal, 2013).

While salinity stress can cause severe disruptions in the plant physiology and morphology, very little is known about how such disturbances might affect the plant susceptibility to pathogens. The threat of increasing salinity in many irrigated areas of the world as well as field observations motivated some researches on the possible interactions between salinity stress and disease development (Besri M., 1993).

\section{MATERIALS AND METHODS}

The experiments were conducted at the University of Agricultural Sciences and Veterinary Medicine Cluj Napoca. We use two varieties of red clover cultivar Select 2 and Rotrif, and two varieties of alfalfa Mădălina and Mihaela. To test the ability of germination under salinity conditions we used the healthy seeds and we also tested the ability to germinate under $\mathrm{NaCl}$ stress on inoculated seeds. Inoculants are applied directly to legume seed so that rhizobia bacteria are readily available to colonize roots as seeds germinate. Inoculation of the seeds was performed in the laboratory under sterile conditions. Seeds of red clover and alfalfa varieties were immersed in the bacterial suspension. Prior to the bacterial suspension was prepared YEMB liquid medium and then made a spectrophotometer reading at OD 600 (Margaret Brown, 1974).

Each variety was tested at 4 salinity graduations $(50 \mathrm{mM}, 100 \mathrm{mM}, 150 \mathrm{mM} \mathrm{NaCl}$ and $300 \mathrm{mM}$ ) and version control without salt $(0 \mathrm{mM} \mathrm{NaCl})$. We used 100 seeds/variety in four repetitions and were stored at $\pm 25^{\circ} \mathrm{C}$.

The seeds were considered to be germinated when the radicle length was $1 \mathrm{~mm}$. Monitoring the seeds was done every day for 12 days, and the following parameters were analyzed:

\section{Mean time to germination (MTG)}

Mean time to germination is an index of seed germination speed and velocity, and calculated by:

MTG $=\frac{\sum(n d) \sum(n d)}{\sum \mathrm{n} \quad \sum \mathrm{n}}$

n: number of germinated seeds during seven days, d: number of day(s),

? $\mathrm{n}$ : total of germinated seeds

\section{Mean daily germination (MDG)}

This is an index of daily germination speed and calculated by:

$\mathrm{MDG}=\frac{F G P}{d} \frac{F G P}{d}$ 
Where:

FGP: final germination percent

$\mathrm{d}$ : test period

\section{Daily germination speed (DGS)}

This index is converse of mean daily germination and calculated by:

$$
\mathrm{DGS}=\frac{1 \quad 1}{M D G M D G}
$$

\section{Coefficient of velocity of germination (CVG)}

This is another index of seed germination speed and velocity and calculated by:

$$
\begin{gathered}
C V G=\frac{G 1+G 2+G 3+\cdots+G n}{(1 x G 1)+(2 x G 2)+\cdots+(n x G n)} \\
\frac{G 1+G 2+G 3+\cdots+G n}{(1 x G 1)+(2 x G 2)+\cdots+(n x G n)}
\end{gathered}
$$

Where:

G1-Gn: number of germinated seeds from the first to the last day (Ashkan și Jalal, 2013).

In addition to these observations because the relatively high number of diseased seeds we establish the frequency of each microorganism pathogen or saprophyte.

\section{RESULTS AND DISCUSSION}

The effect of salinity $(\mathrm{C} 0-0 \mathrm{mM} \mathrm{NaCl}$ to the control, C 1 - $50 \mathrm{mM}, \mathrm{C} 2$ - $100 \mathrm{mM}, \mathrm{C} 3$ - C4 150 $\mathrm{mM}-300 \mathrm{mM} \mathrm{NaCl}$ ) on four varieties of seed germination was observed for 12 days, and every day we noted differences emerged.

In control version ( $0 \mathrm{mM} \mathrm{NaCl}$ ) were observed differences between inoculated and not inoculated variants (Tab. 1). The variety with the highest rate of germination (98\%) was Rotrif to non inoculated variant followed by Mihaela with a germination percentage of $97.5 \%$ this time inoculated variant. To variety Select 2 we noticed the lowest germination rate of only $81.50 \%$.

The lowest average time of germination (MTG) was observed in inoculated variety Mihaela and greatest germination in Select 2 and highest mean daily germination (MDG) (16.33) was observed in variety Rotrif. The higher value of long root were observed in both varieties of alfalfa analyzed (Madalina and Mihaela) in both variants (incoluated and not incoluated). The situation has remained the same in the case of shoot length.

Germination rate was affected by the first concentration of $\mathrm{NaCl}$ compared to the control. At a concentration of $50 \mathrm{mM}$ (C1) germination rate was only $45.0 \%$ and $53.5 \%$ in both treatment used, the treated seeds were more resistant to salinity (Tab. 2). We noticed that the variety Mihaela at control treatment had the highest rate of germination in inoculated treatment $(97 \%)$ and $92.5 \%$ in not inoculated version. Variety Mădălina also developed very well in the first concentration of salt used, the differences between the two varieties of alfalfa are insignificant.

The lowest average time of germination (MTG) was observed in variety Mădălina (2.77) and highest on Select 2 (4.53) both on inoculated version Average germination day (MDG) was directly proportional to the percentage of germination.

Root and shoot length are the most important parameters in the study of salinity testing, because the roots are direct contact and contact with soil absorb water from the soil and plant supplies the rest. For this reason, the length of the root and

\begin{tabular}{|c|c|c|c|c|c|c|c|c|}
\hline Variety & Treatment & $\begin{array}{l}\text { Root length } \\
(\mathrm{cm})\end{array}$ & $\begin{array}{l}\text { Shot length } \\
(\mathrm{cm})\end{array}$ & $\begin{array}{c}\text { Germination } \\
\% \\
\end{array}$ & MTG & MDG & DGS & CVG \\
\hline \multirow{2}{*}{ Select 2} & not inoculated & $2,31^{\mathrm{bcd}}$ & $2,97^{\mathrm{ab}}$ & $81,50^{\mathrm{b}}$ & $3,13^{a}$ & $13,58^{\mathrm{b}}$ & $0,07^{a}$ & $0,32^{\mathrm{d}}$ \\
\hline & inoculated & $1,63^{\mathrm{d}}$ & $3,10^{\mathrm{ab}}$ & $91,00^{\mathrm{ab}}$ & $2,90^{\mathrm{ab}}$ & $15,16^{\mathrm{ab}}$ & $0,07^{\mathrm{ab}}$ & $0,35^{\text {cd }}$ \\
\hline \multirow{2}{*}{ Rotrif } & not inoculated & $2,40^{\text {bcd }}$ & $2,74^{\mathrm{b}}$ & $98,00^{\mathrm{a}}$ & $2,28^{\mathrm{bc}}$ & $16,33^{\mathrm{a}}$ & $0,06^{\mathrm{b}}$ & $0,44^{\mathrm{bcd}}$ \\
\hline & inoculated & $2,15^{\mathrm{cd}}$ & $2,76^{b}$ & $91,00^{\mathrm{ab}}$ & $2,04^{c}$ & $15,16^{\mathrm{ab}}$ & $0,07^{\mathrm{ab}}$ & $0,50^{\mathrm{abc}}$ \\
\hline \multirow{2}{*}{ Mihaela } & not inoculated & $3,47^{\mathrm{ab}}$ & $3,56^{\mathrm{ab}}$ & $96,00^{\mathrm{a}}$ & $2,11^{\mathrm{bc}}$ & $15,99^{a}$ & $0,07^{\mathrm{ab}}$ & $0,47^{\text {abcd }}$ \\
\hline & inoculated & $3,49^{\mathrm{ab}}$ & $3,20^{\mathrm{ab}}$ & $97,50^{\mathrm{a}}$ & $1,68^{c}$ & $16,25^{\mathrm{a}}$ & $0,07^{\mathrm{ab}}$ & $0,60^{\mathrm{a}}$ \\
\hline \multirow{2}{*}{ Mădălina } & not inoculated & $3,25^{\mathrm{abc}}$ & $4,03^{a}$ & $90,50^{\mathrm{ab}}$ & $2,19^{\mathrm{bc}}$ & $15,08^{\mathrm{ab}}$ & $0,07^{\mathrm{ab}}$ & $0,45^{\text {abcd }}$ \\
\hline & inoculated & $3,67^{\mathrm{a}}$ & $2,77^{\mathrm{b}}$ & $90,25^{\mathrm{ab}}$ & $1,95^{c}$ & $15,04^{\mathrm{ab}}$ & $0,07^{\mathrm{ab}}$ & $0,51^{\mathrm{ab}}$ \\
\hline
\end{tabular}
the shoot has considerable seedlings in response

Tab. 1. Means comparison of seed germination and seedling vigor indices to control 
to salt stress (Jamil and Rha, 2004). Root length show significant differences between the different varieties analyzed. The variety Mădălina root length recorded the highest value (3.89) and the variety Select 2 was the most poorly developed. Regarding the length of the shoot, the situation is different, highest value was recorded on Mihaela in non-incolated treatment and the lowest value was observed in Select 2variety.

With increasing salt concentrations decrease of germination can be observed at all four varieties analysed (Tab. 3). At a concentration of $100 \mathrm{mM}$ $\mathrm{NaCl}$ was slow seed germination, the highest being observed in variety Mihaela inoculated version $(94.75 \%)$ while the lowest rate was observed on Select 2 variety not inoculated treatment $(14,5 \%)$, so that the treated seeds had a greater germination rate.

The mean germination (MTG) had the lowest cultivar Select 2 (2.52) and highest variety Rotrif (4.15) both in not inoculated treatment. As the percentage of germination the length of roots and shoot were also affected by the concentration of $100 \mathrm{mM} \mathrm{NaCl}$, the values are lower compared with $50 \mathrm{mM}$ and control.

To $150 \mathrm{mM} \mathrm{NaCl}$ (C3) concentration were observed some differences between treatment variants (Tab. 4). Germination rate observed in previous concentration $(100 \mathrm{mM})$ was maintained at $150 \mathrm{mM}$ concentration. A more particular was observed in Rotrif variety where germination rate was higher in not inoculat treatment $(11 \%)$ than inoculated version which had a germination rate of only $4 \%$. The lowest average time of germination (MTG) was observed in Rotrif variety not incolated version (1.44) and the highest in Mihaela variety in not inoculated treatment (6.03).

Average germination day (MDG) was directly proportional to the rate of germination. Daily germination rate (DGS) had the lowest variety Madalina (0.08) and the largest variety Rotrif (0.87). Germination rate coefficient (CVG) was also analyzed and the lowest values observed in

Tab. 2. Means comparison of seed germination and seedling vigor indices to $50 \mathrm{mM} \mathrm{NaCl}$

\begin{tabular}{|c|c|c|c|c|c|c|c|c|}
\hline Variety & Treatment & $\begin{array}{l}\text { Root length } \\
(\mathrm{cm})\end{array}$ & $\begin{array}{c}\text { Shot length } \\
(\mathrm{cm})\end{array}$ & $\begin{array}{c}\text { Germination } \\
\% \\
\end{array}$ & MTG & MDG & DGS & CVG \\
\hline \multirow{2}{*}{ Select 2} & not inoculated & $1,11^{\mathrm{f}}$ & $2,17^{\mathrm{b}}$ & $45,0^{c}$ & $3,92^{\mathrm{abc}}$ & $7,50^{c}$ & $0,13^{\mathrm{a}}$ & $0,25^{\mathrm{bcd}}$ \\
\hline & inoculated & $1,22^{\mathrm{ef}}$ & $2,58^{\mathrm{b}}$ & $53,5^{\mathrm{bc}}$ & $4,53^{\mathrm{a}}$ & $8,91^{\mathrm{bc}}$ & $0,11^{\mathrm{ab}}$ & $0,22^{\mathrm{d}}$ \\
\hline \multirow{2}{*}{ Rotrif } & not inoculated & $2,15^{\text {cde }}$ & $2,71^{\mathrm{ab}}$ & $73,5^{\mathrm{ab}}$ & $4,33^{\mathrm{ab}}$ & $12,25^{\mathrm{ab}}$ & $0,09^{\mathrm{bc}}$ & $0,23^{\text {cd }}$ \\
\hline & inoculated & $1,83^{\mathrm{def}}$ & $2,91^{\mathrm{ab}}$ & $77,5^{\mathrm{ab}}$ & $4,48^{\mathrm{a}}$ & $12,91^{\mathrm{ab}}$ & $0,08^{\mathrm{bc}}$ & $0,22^{\mathrm{d}}$ \\
\hline \multirow{2}{*}{ Mihaela } & not inoculated & $2,80^{\mathrm{bcd}}$ & $3,52^{\mathrm{a}}$ & $92,5^{\mathrm{a}}$ & $3,03^{\mathrm{bc}}$ & $15,41^{\mathrm{a}}$ & $0,06^{\mathrm{c}}$ & $0,33^{\mathrm{abc}}$ \\
\hline & inoculated & $3,58^{\mathrm{ab}}$ & $2,77^{\mathrm{ab}}$ & $97,0^{\mathrm{a}}$ & $2,86^{c}$ & $16,16^{\mathrm{a}}$ & $0,07^{\mathrm{c}}$ & $0,35^{\mathrm{ab}}$ \\
\hline \multirow{2}{*}{ Mădălina- } & not inoculated & $2,98^{\mathrm{abc}}$ & $3,43^{a}$ & $89,0^{\mathrm{a}}$ & $3,14^{\mathrm{abc}}$ & $14,83^{\mathrm{a}}$ & $0.07^{\mathrm{c}}$ & $0,31^{\text {abcd }}$ \\
\hline & inoculated & $3,89^{a}$ & $2,85^{\mathrm{ab}}$ & $87,5^{\mathrm{a}}$ & $2,77^{c}$ & $14,58^{\mathrm{a}}$ & $0,07^{\mathrm{c}}$ & $0,36^{\mathrm{a}}$ \\
\hline
\end{tabular}

Tab. 3. Means comparison of seed germination and seedling vigor indices to $100 \mathrm{mM} \mathrm{NaCl}$

\begin{tabular}{ccccccccc}
\hline Variety & Treatment & $\begin{array}{c}\text { Root length } \\
(\mathrm{cm})\end{array}$ & $\begin{array}{c}\text { Shot length } \\
(\mathrm{cm})\end{array}$ & $\begin{array}{c}\text { Germination } \\
\%\end{array}$ & MTG & MDG & DGS & CVG \\
\hline \multirow{2}{*}{ Select 2} & not inoculated & $0,69^{\mathrm{c}}$ & $1,15^{\mathrm{e}}$ & $14,5^{\mathrm{e}}$ & $2,52^{\mathrm{a}}$ & $2,41^{\mathrm{e}}$ & $0,49^{\mathrm{a}}$ & $0,58^{\mathrm{a}}$ \\
\cline { 2 - 8 } & inoculated & $0,80^{\mathrm{c}}$ & $1,47^{\mathrm{de}}$ & $25,0^{\mathrm{de}}$ & $4,33^{\mathrm{a}}$ & $4,16^{\mathrm{de}}$ & $0,26^{\mathrm{ab}}$ & $0,24^{\mathrm{a}}$ \\
\hline \multirow{2}{*}{ Rotrif } & not inoculated & $0,77^{\mathrm{c}}$ & $1,84^{\text {cde }}$ & $46,0^{\mathrm{cd}}$ & $3,76^{\mathrm{a}}$ & $7,66^{\mathrm{cd}}$ & $0,13^{\mathrm{b}}$ & $0,27^{\mathrm{a}}$ \\
\cline { 2 - 8 } & inoculated & $0,92^{\mathrm{c}}$ & $2,00^{\mathrm{bcd}}$ & $49,0^{\mathrm{cd}}$ & $4,15^{\mathrm{a}}$ & $8,16^{\mathrm{cd}}$ & $0,12^{\mathrm{b}}$ & $0,25^{\mathrm{a}}$ \\
\hline \multirow{2}{*}{ Mihaela } & \multirow{2}{*}{ not inoculated } & $1,48^{\mathrm{bc}}$ & $2,66^{\mathrm{ab}}$ & $65,5^{\mathrm{bc}}$ & $3,64^{\mathrm{a}}$ & $10,91^{\mathrm{bc}}$ & $0,09^{\mathrm{b}}$ & $0,27^{\mathrm{a}}$ \\
\cline { 2 - 8 } & inoculated & $3,35^{\mathrm{a}}$ & $2,50^{\mathrm{abc}}$ & $94,75^{\mathrm{a}}$ & $3,27^{\mathrm{a}}$ & $15,80^{\mathrm{a}}$ & $0,06^{\mathrm{b}}$ & $0,30^{\mathrm{a}}$ \\
\hline \multirow{2}{*}{ Mădălina } & not inoculated & $2,39^{\mathrm{ab}}$ & $3,07^{\mathrm{a}}$ & $86,0^{\mathrm{ab}}$ & $3,72^{\mathrm{a}}$ & $14,33^{\mathrm{ab}}$ & $0,07^{\mathrm{b}}$ & $0,27^{\mathrm{a}}$ \\
\cline { 2 - 9 } & inoculated & $3,36^{\mathrm{a}}$ & $2,45^{\mathrm{abc}}$ & $88,2^{\mathrm{ab}}$ & $3,59^{\mathrm{a}}$ & $14,70^{\mathrm{ab}}$ & $0,07^{\mathrm{b}}$ & $0,28^{\mathrm{a}}$ \\
\hline
\end{tabular}


Mihaela variety for not inoculated variant and in Rotrif variety for incoluated treatment.

Root length show significant differences between the different varieties analyzed. Concerning root length in red clover cultivars analyzed (Select 2 and Rotrif) we observed a decline of length compare with alfalfa varieties. The Rotrif variety average of root length was of only $0.15 \mathrm{~cm}$ and the longest $(2.83 \mathrm{~cm})$ was observed in Mădălina variety. Situation of shoot length was similar to the root the difference that the Mihaela variety had a better development of shoot length with an average of $2.26 \mathrm{~cm}$.

The highest concentration of salt $(300 \mathrm{mM}$ $\mathrm{NaCl}$ ), its effect has been observed both on germination and development of seedlings, they have also been observed differences between both treatments (inoculated and not inoculated) (Tab. $5)$.

For all not incolated variants analyzed we noticed that they failed to germinate at this concentration of salt and for inoculated treatment varieties analised were able to germinate with mention that the rate was low for all varieties. However Mădălina varieties and Select 2 had the highest rates $(10 \%$ and $3.5 \%)$, while the lowest rate was observed in variety Rotrif sprouting just $0.50 \%$. The highest average germination time (MTG) was observed in Madalina variety (4.39) and the lowest in Rotrif variety (0.50). Average germination day (MDG) was directly proportional to the percentage of germination for all varieties analyzed.

Root and shoot lengths tested in salinity parameters we noticed the highest average was observed on Mădălina variety $(0.28 \mathrm{~cm})$ followed by cultivar Select 2 with a mean of $0.11 \mathrm{~cm}$. The lowest root length was recorded at only $0.02 \mathrm{~cm}$ Rotrif variety, the ranking is identical to the rate of germination. Regarding the situation is different shoot length, abnormal seedlings developed the most germs, and the highest value was the variety Select $2(0.18 \mathrm{~cm})$ and the lowest variety Rotrif (0.02).

Tab. 4. Means comparison of seed germination and seedling vigor indices to $150 \mathrm{mM} \mathrm{NaCl}$

\begin{tabular}{ccccccccc}
\hline Variety & Treatment & $\begin{array}{c}\text { Root length } \\
(\mathrm{cm})\end{array}$ & $\begin{array}{c}\text { Shot length } \\
(\mathrm{cm})\end{array}$ & $\begin{array}{c}\text { Germination } \\
\%\end{array}$ & MTG & MDG & DGS & CVG \\
\hline \multirow{2}{*}{ Select 2} & not inoculated & $0,64^{\mathrm{bc}}$ & $0,64^{\mathrm{b}}$ & $3,50^{\mathrm{c}}$ & $3,79^{\mathrm{ab}}$ & $0,58^{\mathrm{c}}$ & $2,12^{\mathrm{a}}$ & $0,28^{\mathrm{a}}$ \\
\hline & inoculated & $0,54^{\mathrm{c}}$ & $0,51^{\mathrm{b}}$ & $16,5^{\mathrm{c}}$ & $1,44^{\mathrm{b}}$ & $0,58^{\mathrm{c}}$ & $1,31^{\mathrm{ab}}$ & $0,39^{\mathrm{a}}$ \\
\hline \multirow{2}{*}{ Rotrif } & not inoculated & $0,59^{\mathrm{bc}}$ & $0,58^{\mathrm{b}}$ & $11,0^{\mathrm{c}}$ & $3,06^{\mathrm{ab}}$ & $1,83^{\mathrm{c}}$ & $0,55^{\mathrm{b}}$ & $0,33^{\mathrm{a}}$ \\
\cline { 2 - 8 } & inoculated & $0,15^{\mathrm{c}}$ & $0,12^{\mathrm{b}}$ & $4,0^{\mathrm{c}}$ & $3,04^{\mathrm{ab}}$ & $0,67^{\mathrm{c}}$ & $0,87^{\mathrm{ab}}$ & $0,18^{\mathrm{a}}$ \\
\hline \multirow{2}{*}{ Mihaela } & not inoculated & $1,15^{\mathrm{abc}}$ & $1,17^{\mathrm{ab}}$ & $33,5^{\mathrm{bc}}$ & $6,03^{\mathrm{a}}$ & $5,58^{\mathrm{bc}}$ & $0,20^{\mathrm{b}}$ & $0,17^{\mathrm{a}}$ \\
\cline { 2 - 8 } & inoculated & $2,31^{\mathrm{ab}}$ & $2,26^{\mathrm{a}}$ & $60,0^{\mathrm{ab}}$ & $4,31^{\mathrm{ab}}$ & $10,00^{\mathrm{ab}}$ & $0,10^{\mathrm{b}}$ & $0,23^{\mathrm{a}}$ \\
\hline \multirow{2}{*}{ Mădălina } & not inoculated & $1,30^{\mathrm{abc}}$ & $1,29^{\mathrm{ab}}$ & $51,5^{\mathrm{ab}}$ & $4,38^{\mathrm{ab}}$ & $8,58^{\mathrm{ab}}$ & $0,12^{\mathrm{b}}$ & $0,22^{\mathrm{a}}$ \\
\hline & inoculated & $2,83^{\mathrm{a}}$ & $2,21^{\mathrm{a}}$ & $73,7^{\mathrm{a}}$ & $4,00^{\mathrm{ab}}$ & $12,29^{\mathrm{a}}$ & $0,08^{\mathrm{b}}$ & $0,25^{\mathrm{a}}$ \\
\hline
\end{tabular}

Tab. 5. Means comparison of seed germination and seedling vigor indices to $300 \mathrm{mM} \mathrm{NaCl}$

\begin{tabular}{ccccccccc}
\hline Variety & Treatment & $\begin{array}{c}\text { Root length } \\
(\mathrm{cm})\end{array}$ & $\begin{array}{c}\text { Shot length } \\
(\mathrm{cm})\end{array}$ & $\begin{array}{c}\text { Germination } \\
\%\end{array}$ & MTG & MDG & DGS & CVG \\
\hline \multirow{2}{*}{ Select 2} & not inoculated & $0,00^{\mathrm{b}}$ & $0,00^{\mathrm{b}}$ & $0,00^{\mathrm{b}}$ & $0,00^{\mathrm{b}}$ & $0,00^{\mathrm{b}}$ & $0,00^{\mathrm{a}}$ & $0,00^{\mathrm{b}}$ \\
\cline { 2 - 8 } & inoculated & $0,11^{\mathrm{ab}}$ & $0,18^{\mathrm{a}}$ & $3,50^{\mathrm{ab}}$ & $1,73^{\mathrm{ab}}$ & $2,75^{\mathrm{a}}$ & $0,36^{\mathrm{a}}$ & $0,58^{\mathrm{a}}$ \\
\hline \multirow{2}{*}{ Rotrif } & not inoculated & $0,00^{\mathrm{b}}$ & $0,00^{\mathrm{b}}$ & $0,00^{\mathrm{b}}$ & $0,00^{\mathrm{b}}$ & $0,00^{\mathrm{b}}$ & $0,00^{\mathrm{a}}$ & $0,00^{\mathrm{b}}$ \\
\cline { 2 - 8 } & inoculated & $0,02^{\mathrm{b}}$ & $0,02^{\mathrm{ab}}$ & $0,50^{\mathrm{b}}$ & $0,50^{\mathrm{b}}$ & $0,09^{\mathrm{b}}$ & $0,75^{\mathrm{a}}$ & $0,13^{\mathrm{ab}}$ \\
\hline \multirow{2}{*}{ Mihaela } & not inoculated & $0,00^{\mathrm{b}}$ & $0,00^{\mathrm{b}}$ & $0,00^{\mathrm{b}}$ & $0,00^{\mathrm{b}}$ & $0,00^{\mathrm{b}}$ & $0,00^{\mathrm{a}}$ & $0,00^{\mathrm{b}}$ \\
\hline & inoculated & $0,05^{\mathrm{b}}$ & $0,04^{\mathrm{ab}}$ & $1,00^{\mathrm{b}}$ & $2,00^{\mathrm{ab}}$ & $0,17^{\mathrm{b}}$ & $1,50^{\mathrm{a}}$ & $0,13^{\mathrm{ab}}$ \\
\hline \multirow{2}{*}{ Mădălina } & not inoculated & $0,00^{\mathrm{b}}$ & $0,00^{\mathrm{b}}$ & $0,00^{\mathrm{b}}$ & $0,00^{\mathrm{b}}$ & $0,00^{\mathrm{b}}$ & $0,00^{\mathrm{a}}$ & $0,00^{\mathrm{b}}$ \\
\hline & inoculated & $0,28^{\mathrm{a}}$ & $0,00^{\mathrm{b}}$ & $10,00^{\mathrm{a}}$ & $4,39^{\mathrm{a}}$ & $1,66^{\mathrm{ab}}$ & $0,77^{\mathrm{a}}$ & $0,22^{\mathrm{ab}}$ \\
\hline
\end{tabular}


Among all varieties analyzed most of them were affected by salinity by reducing the rate of germination and development of seedlings. The highest concentration of $\mathrm{NaCl}$ seedlings have not developed normally develop abnormal germ number is quite large. Salinity affects seed germination by osmotic effect by preventing or delaying germination, toxicity or ions, causing unviable seed (Cokkizgin, 2012).

\section{CONCLUSION}

Germination rate was affected by the first salinity concentration compared to the control. With increasing of salt concentrations a decrease of germination can be observed in all four varieties analyzed for both incoluated and not inoculated treatments.

Acknowledgments. (This paper was published under the frame of European Social Fund, Human Resources Development Operational Programme 2007-2013, project no. POSDRU/159/1.5/S/132765).

\section{REFERENCES}

1. Ashkan A, Jalal M (2013). Effects of salinity stress on seed germination and seedling vigor indices of two Halophytic plant species (Agropyron elongatum and A. pectiniforme). International Journal of Agriculture and Crop Sciences, 5(22):2669-2676.

2. Benabderrahim MA, Haddad M, Hamza H, Ferchichi A (2011). Germination and emergence variability of alfalfa (Medicago sativa L.) landraces collected in Southern
Tunisia oases. Spanish Journal of Agricultural Research, 9(1):135-143.

3. Besri M (1993). Effect of salinity on plant diseases development In. H. Lieth and A. Al. Massoom (eds): Towards the rational use of high salinity tolerant plants. Vol 2. 67-74.

4. Brown E. Margaret (1974). Seed and root bacterization. Annual Review of Phytopathology. 12:181-197.

5. Castroluna A, Ruiz OM, Quiroga AM, Pedranzani HE (2014). Effects of salinity and drought stress on germination , biomas and growth in three varieties of Medicago sativa $\mathrm{L}$. Advances en Invetigación Agropecuria 18(1): 39-50.

6. Cokkizgin A (2012). Salinity stress in common bean (Phaseolus vulgaris L.) seed germination. Not.Bot. Horti Agrobo. 40(1):177-182.

7. Hasanuzzaman M, Kamrun N, Masayuki F (2013). Plant response to salt stress and role of exogenous protectants to mitigate salt-induced damages, in Ecophysiology and Responses of Plants under Salt Stress (eds P. Ahmad, M.M. Azooz, and M.N.V. Prasad), Springer, New York, pp. 25-87.

8. Mandić V, Krnjaja V, Bijelić Z, Tomić Z, Simić A, RužićMuslić D, Stanojković A (2014). Genetic variability of red clover seedlings in relation to salt stress. Botechnology in Animal Husbandry. 30(3):529-538.

9. Orak A, Ateş E (2005). Resistance to salinity stress and available water levels at the seedling stage of the common vetch (Vicia sativa L.). Plant Soil Environ 51(2):51-56.

10. Ozlem Onal Asci (2011). Salt tolerance in red clover (Trifolium pratense L.) seedlings, African Journal of Biotechnology. 10(44):8774-8781.

11. Ruili Li, Fuchen S, Kenji F, Yongli Y (2010). Effects of salt and alkali stresses on germination, growth, photosynthesis and ion accumulation in alfalfa (Medicago sativa L.). Soil Science \& Plant Nutrition 56(5):725-733.

12. Scasta JD, Trostle LC, Foster AM (2012). Evaluating alfalfa (Medicago sativa L.) cultivars for salt tolerance using laboratory, greenhouse and field methods. Journal of Agricultural Sciences. 4(6):90-103. 